\title{
ANALISIS PENCEMARAN AIR MENGGUNAKAN METODE SEDERHANA PADA SUNGAI JANGKUK, KEKALIK DAN SEKARBELA KOTA MATARAM
}

\author{
Syarifa Wahidah Al Idrus \\ Program Studi pendidikan kimia, Jurusan PMIPA Universitas Mataram \\ Jl. Majapahit No 62 Mataram 83125, telp 0370-623873, fax 0370-634918 \\ Email : idahsya76@yahoo.co.id
}

\begin{abstract}
Abstrak: Telah dilakukan penelitian tentang analisis pencemaran air menggunakan metode sederhana pada sungai jangkuk, kekalik dan sekarbela, provinsi NTB. Tujuan dari penelitian ini untuk mengetahui pencemaran yang terjadi pada ketiga sungai tersebut dilihat dari uji fisik, uji kimia dan uji biologis secara sederhana. Penelitian ini menggunakan alat dan bahan yang banyak dijumpai sehingga masyarakat dapat menganalisis sendiri untuk membuktikan kondisi air yang digunakan. Dari hasil pengamatan yang dilakukan secara fisik, ketiga sungai tersebut mengalami pencemaran dari segi bau, warna dan suhu. Berdasarkan pengujian secara biologi terdapat aktivitas biologis dan kimiawi mikroorganisme. Hasil pengujian secara kimia, maka dapat diketahui $\mathrm{pH}$ sampel air tersebut sebesar 5 (bersifat asam), kemudian pengujian kimia ini juga dilakukan dengan teh, terdapat gumpalan hitam pada ketiga sampel air, perubahan warna menjadi gelap dan lapisan minyak pada permukaan air yang menunjukkan kualitas air tidak dapat dijadikan bahan baku air minum. Penyebab pencemaran air pada ketiga sungai tersebut adalah limbah rumah tangga, limbah pertanian dan limbah industri. Kondisi ini dapat diatasi dengan melestarikan hutan di hulu sungai, dan tidak membuang limbah ke sungai baik cair ataupun padat.
\end{abstract}

Kata kunci: analisi, pencemaran air, metode sederhana, sungai jangkuk, kekalik dan sekarbela

\begin{abstract}
Research on waters' pollution analysis have been conducted by simple analytical method at Jangkuk, Kekalik and Sekarbela rivers, West Nusa Tenggara Province. The aim of this research is to find out the waters' pollution at those three rivers by looking at its physical, chemical, and biological test with a simple method. This research used daily tools and materials which easy to find so that ordinary people could analyze and prove the condition of the water in which they used every day. From the result of physical test, it showed that three of those rivers were polluted in term of smell, color, and temperature aspects. Based on biological test, it showed that there are activities of biological and chemical microorganisms on the water. From its chemical test, it showed that the $\mathrm{pH}$ of the sample water is 5 (positively acid). The chemical test found black spot at those three samples of water if filtered by tea. The water's color changed brown and found some oilly compound at the surface. This condition showed that the water's qualities are bad and not suitable to be consumed. The causes of the water pollution are mostly from home, agricultural, and industrial trashes. This problem could be solved by replanting the river side and not throwing the trashes materials (liquid or solid materials) into the rivers.
\end{abstract}

Keywords: Analysis, Water Pollution, simple method, Jangkuk River, Kekaik River, Sekarbela River.

\section{PENDAHULUAN}

Air merupakan kebutuhan utama bagi proses kehidupan di bumi, sehingga tidak ada kehidupan seandainya tidak ada air di bumi. Namun, air dapat menjadi malapetaka jika tersedia dalam kondisi yang tidak benar, baik kualitas maupun kuantitas airnya. Air yang bersih sangat dibutuhkan manusia, baik untuk keperluan sehari - hari, untuk keperluan industri, untuk kebersihan sanitasi kota, dan sebagainya. Saat ini air menjadi masalah yang memerlukan perhatian serius. Untuk mendapatkan air yang baik sesuai dengan standar tertentu sudah cukup sulit untuk didapatkan. Hal ini dikarenakan air sudah banyak tercemar oleh bermacam - macam limbah dari berbagai hasil kegiatan manusia. Sehingga menyebabkan kualitas air menurun, begitupun dengan kuantitasnya. Pemanfaatan air untuk berbagai kepentingan harus dilakukan secara bijaksana, dengan memperhitungkan kepentingan generasi sekarang maupun generasi mendatang. Aspek pengamatan dan pelestarian sumber daya air harus ditanam pada segenap pengguna air [4].

Kondisi air tercemar bisa terjadi di daerah perkotaan maupun pedesaan, seperti di Teluk Jakarta yang berakibat bagi para petambak. Bukan hanya beberapa spesies ikan yang hilang, tetapi udang dan bandeng juga banyak yang mati. Secara kimiawi pencemaran yang terjadi di Teluk Jakarta termasuk cukup parah. Sehingga indikator pencemar seperti kerang hijau terlah berkembang secara pesat. Selain itu, penggunaan pestisida yang berlebihan dan berlangsung lama juga akan berakibat terjadinya pencemaran air. Seperti yang terjadi di NTB, dimana terjadi pencemaran air akibat penggunaan pestisida 
yang berlebihan dalam waktu yang lama. Petani menggunakan pestisida di sekitar mata air Lingsar dan Ranget [1].

Semua orang berharap bahwa seharusnya air diperlakukan sebagai bahan yang sangat bernilai, dimanfaatkan secara bijak, dan dijaga terhadap cemaran. Namun kenyataannya air selalu dihamburkan, dicemari, dan disia-siakan. Hampir sebagian penduduk dunia di negara-negara berkembang, menderita berbagai penyakit yang diakibatkan oleh kekurangan air, atau oleh air yang tercemar. Menurut Organisasi Kesehatan Dunia, 2 miliar orang kini menyandang risiko menderita penyakit murus yang disebabkan oleh air dan makanan. Penyakit ini merupakan penyebab utama kematian lebih dari 5 juta anak-anak setiap tahun [5].

Krisis air juga terjadi hampir di semua Pulau Jawa dan sebagian Sumatera, terutama kota - kota besar baik akibat pencemaran limbah cair industri, rumah tangga maupun pertanian. Selain menurunnya kualitas air akibat pencemaran, krisis air juga terjadi dari kurangnya ketersediaan air dan terjadinya erosi akibat pembabatan hutan di hulu serta perubahan pemanfaatan lahan di hulu dan hilir. Pencemaran air yang terjadi di berbagai wilayah di Indonesia, seperti beberapa contoh di atas, telah mengakibatkan terjadinya krisis air bersih. Lemahnya pengawasan pemerintah serta keengganan untuk melakukan penegakan hukum secara benar menjadikan problem pencemaran air menjadi hal yang kronis yang makin lama makin parah.

Kondisi pencemaran air bisa juga terjadi di beberapa daerah kecil yang memiliki industri yang tidak terlalu banyak, Seperti di Lombok NTB. Hal ini bisa terlihat dari kondisi sungai yang kotor jika terlihat secara fisik. Beberapa sungai yang terletak sangat strategis di kota Mataram seperti sungai jangkuk, kekalik dan sekarbela secara fisik lingkungan sekitar sungai sangat kotor. Air sungai ini digunakan oleh penduduk untuk mandi, mencuci dan memancing ikan di lingkungan sungai, padahal, secara fisik lingkungan sekitar sungai ini sangat kotor oleh sampah karena sungai ini digunakan sebagai tempat pembuangan sampah. Dengan demikian, air sungai ini sangat mungkin mengalami pencemaran. Menurut warga sekitar sungai, mereka yang telah menggunakan air sungai untuk berbagai aktivitasnya mengalami gatal-gatal, sehingga perlu dibuktikan pencemaran yang terjadi pada ketiga air sungai (jangkuk, kekalik dan sekarbela) melalui beberapa metode sederhana sehingga masyarakat mengetahui kondisi sungai tersebut dan bisa melakukan analisis sederhana untuk mengetahui kualitas air yang akan dikonsumsi, dan mengetahui faktor-faktor penyebab pencemarannya dan bagaimana cara menangguanginya.
Salah satu indikator yang digunakan dalam analisis air secara sederhana adalah pengujian menggunakan air teh. Alasan penggunaan seduhan air teh pada uji kimia ini adalah karena kemampuan air untuk mengekstraksi komponen teh terutama kafein pada teh. Kemampuan air untuk mengekstraksi akan berkurang bila kandungan zat terlarutnya pada sampel air sungai sangat tinggi. Jika air yang digunakan untuk menyeduh teh bersifat sadah sementara, maka $\mathrm{Ca}\left(\mathrm{HCO}_{3}\right)_{2}$ dan $\mathrm{Mg}\left(\mathrm{HCO}_{3}\right)_{2}$ akan bereaksi dengan asam dan membentuk garam garam $\mathrm{Ca}$ dan $\mathrm{Mg}$ dengan melepaskan $\mathrm{CO}_{2}$ sehingga warna seduhan menjadi gelap.

\section{METODE PENELITIAN}

Penelitian ini dilaksanakan di beberapa titik pada sungai Jangkuk, Kekalik dan Sekarbela dan di laboratorium kimia FKIP universitas Mataram. Penelitian dilaksanakan pada bulan April 2014, metode yang digunakan adalah observasi dan eksperimen.

Alat dan Bahan sederhana yang digunakan dalam penelitian ini adalah:

1. Uji fisika sederhana

Sampel air sungai sekarbela, air sungai jangkuk, air sungai kekalik, aquades, dan kertas label. Gelas kimia, enlemeyer, pipet tetes, botol air minum plastic, termometer, gelas ukur.

2. Uji kimia sederhana

Air teh, sampel air sungai sekarbela, air sungai jangkuk, air sungai kekalik, kertas indikator ph, Aquades, Kertas label. Erlenmeyer, gelas kimia, hot plate, cawan petri, gelas ukur.

3. Uji biologi sederhana

Sampel air sungai sekarbela, air sungai jangkuk, air sungai kekalik, aquades, plastic, karet, kertas label, botol kaca bening

Pengamatan

1. Uji fisika sederhana

Sampel (air sungai jangkuk, kekalik dan sekarbela) $50 \mathrm{ml}$ dalam erlenmeyer masing-masing diukur suhu air dan ditambahkan $25 \mathrm{ml}$ aquades, dan diperhatikan perubahan yang terjadi berupa perubahan warna, kekeruhan, suhu dan bau. Sebagai kontrol aquades $25 \mathrm{ml}$ dalam erlenmeyer tanpa sampel.

2. Uji kimia sederhana

Pengukuran $\mathrm{pH}$ air sampel menggunakan kertas indikator. Dalam $100 \mathrm{ml}$ air sampel masing-masin sungai dalam erlenmeyer ditambahkan $50 \mathrm{ml}$ air teh, dan dibiarkan selama semalam pada kondisi terbuka baru diamati.

3. Uji biologi 
Masing-masing sampel air dimasukkan ke dalam botol kaca bening dan didiamkan selama lima hari dan diamati perubahannya.

\section{HASIL DAN PEMBAHASAN}

\section{A. Uji fisika}

Hasil uji secara fisika pada ketiga sampel air sungai tersebut menunjukkan bahwa air sungai dari ketiga daerah telah tercemar dengan ciri-ciri fisik seperti bau yang menyengat, warna air sangat keruh, dan suhu yang tinggi yang dapat merusak ekosistem dan biota air. Perbandingan ketiganya air jangkuk lebih bersih dibanding air kekalik dan sekarbela., ketiga air sungai sangat keruh, kekeruhan sampel air disebabkan oleh partikel-partikel yang tersuspensi dalam air, baik yang bersifat anorganik maupun organik. Zat anorganik, biasanya berasal dari lapukan tanaman dan hewan. Buangan industri juga dapat menyebabkan kekeruhan. Zat organik dapat menjadi makanan bakteri, sehingga mendukung perkembang biakannya. Kualitas air yang baik adalah jernih (bening) dan tidak keruh.

Ketiga sampel air sungai memiliki bau yang sangat menyengat. Air yang mempunyai kualitas baik adalah tidak berbau. Bau dapat dirasakan langsung oleh indera penciuman. Air yang mempunyai bau mengindikasikan ada terjadi proses dekomposisi bahan - bahan organic oleh mikroorganisme dalam air, disebabkan oleh senyawa fenol yang terdapat dalam air atau penyebab lainnya yang menyebabkan air tidak tidak layak dikonsumsi. Air minum yang berbau selain tidak estetis juga tidak akan disukai oleh masyarakat. Bau air dapat memberi petunjuk akan kualitas air. Misalnya, bau amis dapat disebabkan oleh tumbuhnya Algae.

Suhu ketiga sungai berkisar antara 29-30 C, air yang baik mempunyai suhu normal yakni $25^{\circ} \mathrm{C}$. Suhu air yang melebihi batas normal menunjukkan indikasi terdapat bahan kimia yang terlarut dalam jumlah yang cukup besar atau sedang terjadi proses dekomposisi bahan organik oleh mikroorganisme. Warna pada air dapat disebabkan oleh macam macam bahan kimia atau organik. Air yang layak dikosnsumsi harus jernih dan tidak berwarna.
Air dalam keadaan normal memiliki karakteristik yang bersih dan tidak bewarna. Biasanya perubahan warna dikarenakan adanya macam-macam warna bahan buangan dari suatu industri seperti industri tekstil. Namun belum tentu air bewarna lebih berbahaya dari pada air yang tidak bewarna. Sedangkan perubahan bau biasanya dikarenakan kandungan protein yang berasal dari limbah industri. Perubahan rasa dikarenakan adanya perubahan asam dan basa tercampur bahan tercemar lainnya. Industri yang melakukan pembuangan limbah disekitar sungai jangkuk dan kekalik sebagian besar adalah industri rumah tangga pembuatan tahu tempe, sedang untuk sungai sekarbela ada pembuangan limbah industri kerajinan emas.

Secara keseluruhan perubahan warna, bau, rasa, $\mathrm{pH}$ dan suhu dikarenakan masuknya limbah ke dalam aliran sungai secara langsung tanpa adanya pengolahan limbah terlebih dahulu. Dari kondisi fisik sungai bisa dikatakan sungai mengalami pencemaran. Polusi atau pencemaran lingkungan adalah masuknya atau dimasukkannya makhluk hidup, zat energi, dan/atau komponen lain ke dalam lingkungan, atau berubahnya tatanan lingkungan oleh kegiatan manusia atau oleh proses alam sehingga kualitas lingkungan turun sampai ke tingkat tertentu yang menyebabkan lingkungan menjadi kurang atau tidak berfungsi lagi sesuai dengan peruntukkannya (Undang-undang Pokok Pengelolaan Lingkungan Hidup No 4 Tahun 1982).

Sumber-sumber air semakin dicemari oleh limbah industri yang tidak diolah atau tercemar karena penggunaan yang melebihi kapasitasnya untuk dapat diperbaharui. Kalau kita tidak mengadakan perubahan radikal dalam cara kita memanfaatkan air, mungkin saja suatu ketika air tidak lagi dapat digunakan tanpa pengolahan khusus yang biayanya melewati jangkauan sumber daya ekonomi bagi kebanyakan negara [5]. Sumber kehidupan ini persediaannya terbatas dan semakin hari semakin terpolusi oleh kegiatan manusia sendiri, namun masih terlalu banyak orang yang tidak mempunyai akses ke air. Sekalipun air merupakan sumber daya yang terbatas, konsumsi air telah meningkat dua kali lipat dalam 50 tahun terakhir dan kita gagal mencegah terjadinya penurunan mutu air.

Tabel 1 Perbedaan suhu dan warna sampel air sungai

\begin{tabular}{|c|c|c|c|c|}
\hline \multicolumn{2}{|c|}{ Uji Fisika } & $\mathbf{T}_{\text {awal }}\left({ }^{\circ} \mathbf{C}\right)$ & $\mathbf{T}_{\text {campuran }}\left({ }^{\circ} \mathbf{C}\right)$ & Warna dan bau \\
\hline $\begin{array}{l}\text { Sampel Ai } \\
\text { Jangkuk }\end{array}$ & Sungai & 30 & 29 & $\begin{array}{l}\text { Warna awal keruh setelah ditambah aquades } \\
\text { kekeruhan air berkurang, bau menvengat }\end{array}$ \\
\hline $\begin{array}{l}\text { Sampel Ai } \\
\text { Kekalek }\end{array}$ & Sungai & 29 & 28,5 & $\begin{array}{l}\text { Warna awal keruh setelah ditambah aquades } \\
\text { kekeruhan air berkurang, bau menyengat }\end{array}$ \\
\hline $\begin{array}{l}\text { Sampel Ai } \\
\text { Sekarbela }\end{array}$ & Sungai & 30 & 29 & $\begin{array}{l}\text { Warna awal keruh setelah ditambah aquades } \\
\text { kekeruhan air berkurang, bau menyengat }\end{array}$ \\
\hline
\end{tabular}




\section{B. Uji Kimia}

Setelah disimpan sehari semalam, sampel air sungai yang telah dicampur seduhan teh terdapat gumpalan hitam, perubahan warna menjadi gelap dan lapisan minyak pada permukaan air yang menunjukkan kualitas air tidak dapat dijadikan bahan baku air minum. Alasan penggunaan seduhan air teh pada uji kimia ini adalah karena kemampuan air untuk mengekstraksi komponen teh terutama kafein pada teh. Kemampuan air untuk mengekstraksi akan berkurang bila kandungan zat terlarutnya pada sampel air sungai sangat tinggi. Jika air yang digunakan untuk menyeduh teh bersifat sadah sementara, maka $\mathrm{Ca}\left(\mathrm{HCO}_{3}\right)_{2}$ dan $\mathrm{Mg}\left(\mathrm{HCO}_{3}\right)_{2}$ akan bereaksi dengan asam dan membentuk garam - garam $\mathrm{Ca}$ dan $\mathrm{Mg}$ dengan melepaskan $\mathrm{CO}_{2}$ sehingga warna seduhan menjadi gelap. Sesuai dengan persamaan berikut ini:

$\mathrm{Ca}\left(\mathrm{HCO}_{3}\right)_{2}{ }_{(\mathrm{aq})}+\mathrm{H}^{+}{ }_{(\mathrm{aq})} \rightarrow \mathrm{CaCO}_{3}(\mathrm{~s})+\mathrm{CO}_{2}(\mathrm{~g})+\mathrm{H}_{3} \mathrm{O}^{+}$ (aq)

$\mathrm{Mg}\left(\mathrm{HCO}_{3}\right)_{2(\mathrm{aq})}+\mathrm{H}^{+}{ }_{(\mathrm{aq})} \rightarrow \mathrm{MgCO}_{3}(\mathrm{~s})+\mathrm{CO}_{2}(\mathrm{~g})+\mathrm{H}_{3} \mathrm{O}^{+}$ (aq)

Semakin cepat perubahan yang terjadi pada air teh menunjukkan semakin tinggi kandungan kimiawi air tersebut. Bila perubahannya lambat atau baru berubah setelah pengamatan satu malam, kandungan kimiawinya lebih sedikit, namun tetap air itu kurang baik dikonsumsi. Dapat digunakan untuk keperluan lain, kecuali untuk dikonsumsi. Air yang mengandung tingkat kesadahan dan kandungan logam tinggi dapat terlihat bila air teh berubah menjadi hitam, ungu atau biru. Bila air tetap berwarna seperti air teh, maka secara kimia kualitas air itu baik.

Selain menggunakan seduhan teh untuk uji kimia, dilakukan uji menggunakan indikator universal untuk mengetahui $\mathrm{pH}$ dari ketiga sampel air sungai. Dari hasil pengujian menunjukkan bahwa $\mathrm{pH}$ dari sampel air adalah 5. Dari hasil ini menunjukkan bahwa air sungai Jangkuk, Sekarbela dan Kekalek bersifat asam dan tidak layak untuk digunakan. Hal ini sesuai dengan peraturan Permenkes bahwa air yang memiliki kualitas baik adalah air yang memiliki $\mathrm{pH} 7(\mathrm{pH}$ netral).

Parameter $\mathrm{pH}$ atau tingkat asiditas atau alkalinitas suatu sampel diukur berdasarkan skala $\mathrm{pH}$ yang dapat menunjukkan konsentrasi ion hydrogen dalam larutan tersebut. Reaksi kimia banyak dikendalikan oleh nilai $\mathrm{pH}$ dan demikian pula aktivitas biologi yang biasanya dibatasi oleh rentang $\mathrm{pH}$ yang sangat sempit ( $\mathrm{pH}$ antara 6-8). Air yang terlalu asam atau basa tidak dikehendaki oleh karena akan bersifat korosif atau kemungkinan akan sulit diolah.
Parameter $\mathrm{pH}$ merupakan istilah yang digunakan untuk menyatakan intensitas keadaan asam atau basa sesuatu larutan. $\mathrm{pH}$ juga merupakan satu cara untuk menyatakan konsentrasi ion $\mathrm{H}^{+}$. Dalam penyediaan air, $\mathrm{pH}$ merupakan satu faktor yang harus dipertimbangkan mengingat bahwa derajat keasaman dari air akan sangat mempengaruhi aktivitas pengolahan yang akan dilakukan, misalnya dalam melakukan koagulasi kimiawi, pelunakan air (water softening) dan pencegahan korosi.

$\mathrm{pH}$ air dimanfaatkan untuk menentukan indeks pencemaran dengan melihat tingkat keasaman atau kebasaan air, terutama oksidasi sulfur dan nitrogen pada proses pengasaman dan oksidasi kalsium dan magnesium pada proses pembasaan. Angka indeks yang umum digunakan 0 sampai 14 dan merupakan angka logaritmik negatif dari konsentrasi ion hydrogen di dalam air. Angka pH 7 adalah netral, sedangkan angka $\mathrm{pH}$ lebih besar dari 7 menunjukkan air bersifat basa dan terjadi ketika ion-ion karbonat dominan, dan $\mathrm{pH}$ lebih kecil dari 7 menunjukkan air bersifat asam [2].

\section{Uji Biologis}

Analisa kualitas air secara biologis bertujuan untuk mengetahui ada atau tidaknya bakteri dalam air. Secara langsung tidak dapat diketahui keberadaan mikroorganisme. Namun, ini dapat dilakukan dengan uji sederhana yaitu dengan cara mendiamkan air selama beberapa hari, pada penelitian ini didiamkan selama lima hari. Dari hasil perlakuan uji biologis ini diperoleh data bahwa:

- hari pertama sampai hari kedua : keadaan air biasa saja

- hari ketiga : terdapat endapan kotoran berwarna coklat

- hari keempat dan kelima : terdapat lumut pada dasar wadah sampel air sungai.

Endapan kotor berwarna coklat lebih banyak ditemukan pada air sungai Kekalek daripada air sungai Sekarbela dan Jangkuk. Dan lumut lebih banyak tumbuh pada sampel air sungai Sekarbela daripada air sungai Kekalik dan Jangkuk. Adanya endapan dan lumut pada sampel air tersebut menunjukkan bahwa adanya aktivitas biologis dan kimiawi mikroorganisme yang mengkontaminasi kandungan air dan dapat merusak ekosistem serta biota air.

\section{Faktor - Faktor Penyebab Pencemaran Air Sungai.}

Perubahan pola pemamfaatan lahan menjadi lahan pertanian, tegalan dan pemukiman serta meningkatnya aktivitas industri akan 
memberikan dampak terhadap kondisi hidrologis dalam suatu Daerah Aliran Sungai (DAS). Selain itu, berbagai aktivitas manusia dalam memenuhi kebutuhan hidupnya yang berasal dari kegiatan industri, rumah tangga dan pertanian akan menghasilkan limbah yang memberikan dampak negatif dan menurunkan kualitas air sungai [6].

Pada dasarnya pencemaran air sungai di kota Mataram disebabkan oleh beberapa factor. Beberapa faktor tersebut diantaranya adalah[3]:

1) Berkembangnya industri.

Saat ini industri - industri di Indonesia semakin berkembang, baik jumlah, teknologi, tingkat produksi maupun limbah yang dihasilkan. Industri - industri khususnya industri tahu dan tempe yang berada di daerah Kekalek dan hasil penyulingan emas yang berada di daerah Sekarbela yang berada di dekat aliran sungai cenderung akan membuang limbahnya ke dalam sungai yang dapat mencemari ekosistem air, karena pembuangan limbah industri ke dalam sungai dapat menyebabkan berubahnya susunan kimia, bakteriologi, serta sifat fisik air. Polutan yang dihasilkan oleh pabrik dapat berupa: Logam berat: raksa $(\mathrm{Hg})$ hasil penyulingan emas di Sekarbela. Panas: air yang tinggi temperaturnya yang dihasilkan dari pembuatan tahu dan tempe di Kekalek sulit menyerap oksigen $\left(\mathrm{O}_{2}\right)$ yang pada akhirnya akan mematikan biota air.

2) Belum tertanganinya pengendalian limbah rumah tangga.

Limbah rumah tangga yang belum terkendali merupakan salah satu faktor yang menyebabkan pencemaran lingkungan khususnya air sungai. Karena dari limbah rumah tangga dihasilkan beberapa zat organik dan anorganik yang dibuang dan dialirkan melalui parit dan akhirnya bermuara ke sungai. Selain dalam bentuk zat organik dan anorganik, dari limbah rumah tangga bisa juga membawa bibit - bibit penyakit yang dapat menular pada hewan dan manusia sehingga menimbulkan epidemik yang luas di masyarakat.

3) Pembuangan limbah pertanian tanpa melalui proses pengolahan.

Limbah pertanian biasanya dibuang ke aliran sungai tanpa melalui proses pengolahan, sehingga dapat mencemari air sungai karena limbah pertanian mengandung berbagai macam zat pencemar seperti pupuk dan pestisida. Penggunaan pupuk di daerah pertanian akan mencemari air yang keluar dari pertanian karena air ini mengandung bahan makanan bagi ganggang dan tumbuhan air seperti kangkung sehingga ganggang dan tumbuhan air tersebut mengalami pertumbuhan dengan cepat yang dapat menutupi permukaan air dan berpengaruh buruk pada ikan - ikan dan komponen ekosistem biotik lainnya. Penggunaan pestisida juga dapat mengganggu ekosistem air kerena pestisida bersifat toksit dan akan mematikan hewan - hwan air, burung dan bahkan manusia.

4) Pencemaran air sungai karena proses alam

Proses alam juga berpengaruh pada pencemaran air sungai misalnya terjadinya gunung meletus, erosi dan iklim. Gunung meletus dan erosi dapat membawa berbagai bahan pencemaran salah satunya berupa endapan/sediment seperti tanah dan lumpur yang dapat menyebabkan air menjadi keruh, masuknya sinar matahari berkurang, dan air kurang mampu mengasimilasi sampah. Iklim juga berpengaruh pada tingkat pencemaran air sungai misalnya pada musim kemarau volume air pada sungai akan berkurang, sehingga kemampuan sungai untuk menetralisir bahan pencemaran juga berkurang.

\section{E. Cara Mencegah Pencemaran Air Sungai}

Jumlah manusia terus bertambah dan kebutuhannya pun terus meningkat. Kebutuhan tersebut dapat berupa kebutuhan primer maupun sekunder. Kebutuhan primer merupakan kebutuhan pokok yaitu makanan, pakaian, perumahan, sedangkan kebutuhan sekunder merupakan kebutuhan tambahan berupa kebutuhan rekreasi, transportasi dan lain lain.

Berbagai kebutuhan tersebut dapat dipenuhi dengan memanfaatkan berbagai jenis sumberdaya alam, baik sumberdaya alam yang dapat diperbarui maupun yang tidak dapat diperbarui. Pengambilan yang dilakukan secara terus menerus berdampak pada semakin berkurangnya cadangan sumberdaya alam, khususnya yang tidak dapat diperbarui. Pengambilan dan pemanfaatan sumberdaya alam juga menimbulkan kerusakan lingkungan yang mengancam keberadaan manusia itu sendiri.

Kondisi diatas salah satu penyebab terjadinya pencemaran air, beberpa cara bisa dilakukan untuk mencegah dan menanggulangi pencemaran air adalah:

a) Melestarikan hutan di hulu sungai.

Agar tidak menimbulkan erosi tanah di sekitar hulu sungai sebaiknya pepohonan tidak digunduli atau ditebang atau merubahnya menjadi areal pemukiman penduduk. Dengan adanya erosi otomatis akan membawa tanah, pasir, dan sebagainya ke aliran sungai dari hulu ke hilir sehingga menyebabkan pendangkalan sungai.

b) Tidak membuang kotoran manusia di sungai.

Buang air kecil dan air besar sembarangan adalah perbuatan yang salah. Kesan pertama dari tinja atau urin yang dibuang sembarangan adalah bau dan menjijikan. Tinja juga merupakan medium yang paling cepat untuk perkembangan bibit penyakit dari yang ringan sampai yang berat, oleh karena itu janganlah buang air besar sembarangan khususnya di sungai.

c) Tidak membuang sampah di sungai. 
Sampah yang dibuang sembarangan di sungai akan menyababkan aliran air di sungai terhambat. Selain itu juga sampah juga akan menyebabkan sungai cepat dangkal dan akhirnya memicu terjadinya banjir di musim penghujan, sampah juga membuat sungai tampak kotor menjijikan dan terkontaminasi.

d) Tidak membuang limbah rumah tangga dan industri ke sungai.

Tempat yang paling mudah untuk membuang limbah industri atau limbah rumah tangga yang berupa cairan adalah dengan mambuangnya ke sungai. Limbah yang dibuang secara langsung tanpa ada pengolahan terlebih dahulu tentu saja dapat menimbulkan pencemaran mulai dari bau yang tidak sedap, pencemaran air, bahaya penyakit kulit serta masih banyak lagi. Kondisi ini yang terjadi pada ketiga sungai yang diamati.

\section{KESIMPULAN}

Berdasarkan hasil pengamatan menggunakan metode sederhana disimpulkan bahwa :

a. Berdasarkan pengujian secara fisik sampel air dari ketiga sungai tersebut tercemar dari segi bau, warna dan suhu.

b. Berdasarkan pengujian secara biologi dapat diamati pada dasar wadah sampel air terdapat lumut yang disebabkan aktivitas biologis dan kimiawi mikroorganisme yang mengkontaminasi kandungan air dan dapat merusak ekosistem serta biota air.

c. Berdasarkan pengujian secara kimia, dapat diketahui $\mathrm{pH}$ sampel air sebesar 5 (bersifat asam), kemudian pengujian kimia ini juga dilakukan dengan cara mencampurkan larutan sampel dengan teh, maka dapat diamati pada larutan tersebut terdapat gumpalan hitam, perubahan warna menjadi gelap dan lapisan minyak pada permukaan air yang menunjukkan kualitas air tidak dapat dijadikan bahan baku air minum.

d. Faktor - faktor yang mempengaruhi pencemaran air sungai yakni, berkembangnya industri - industri, belum tertanganinya pengendalian limbah rumah tangga, pembuangan limbah pertanian tanpa melalui proses pengolahan dan pencemaran air sungai karena proses alam.

e. Cara mengatasi pencemaran air sungai tersebut yakni melestarikan hutan di hulu sungai, tidak membuang kotoran manusia di sungai, tidak membuang sampah di sungai, tidak membuang limbah rumah tangga dan industri ke sungai.

\section{DAFTAR PUSTAKA}

[1] Anonymous. 2008. Water Pollution. http://en.wikipedia.org/wiki/Water_polluti on/, diakses pada tanggal 6 Mei 2014.

[2] Asdak, C., 1995. Hidrologi dan Penelolaah Daerah Aliran Sungai. Penerbit Gadjah Mada University Press. Yogyakarta.

[3] Chandrataruna, Ahmad. 2010. Apa Penyebab Polusi Air. http://id.shvoong.com/ exactsciences/astronomy/2011490-apapenyebab-polusi-air/, diakses pada tanggal 6 Mei 2014.

[4] Effendi, H.2003. Telaah Kualitas Air Bagi Pengelolaan Sumber Daya dan Lingkungan Peraiaran. Penerbit: Kanisius. Yogyakarta.

[5] Midelton, R. 2014. Sumber daya yang rawan. rykhu.wordpress.com/pengolahan-airbersih/. Diakses tanggal 8 agustus 2014

[6] Suriawiria., Unus. 2003. Air dalam Kehidupan dan Lingkungan yang Sehat. Penerbit Alumni. Bandung. 